\title{
Comparing Immigration Detention in Britain and France: A Matter of Time?
}

\author{
Mary Bosworth \& Marion Vannier* \\ University of Oxford and Monash University resp. University of Oxford
}

\begin{abstract}
In this article, we explore the human rights implications of immigration detention in Britain and France by focusing on duration. In so doing, we show how practices in both systems fail to meet basic human rights protections, raising urgent questions about the legitimacy and justification of these sites of confinement. Whereas in the UK problems arise from the absence of a statutory upper time limit to detention, in France it is the brevity for which foreign nationals may be held that raises humanitarian concerns. In the UK, the uncertain duration of detention makes it difficult for detainees to obtain or retain legal advice. Those who are held for long periods of time struggle to maintain their right to family life, while most find the lack of clarity about the period of their confinement hard to endure. In France, where most detainees are released or deported within a matter of days, it is often difficult to access due process and legal protections in time. This brief period of confinement before expulsion contrasts with its enduring effect on their family ties and future. Drawing on policy documents, law, and the limited body of empirical material available on these carceral sites, we map the similarities and differences between them in order to identify the limits as well as some prospects of human rights in immigration detention.
\end{abstract}

Key words

Immigration detention; France; UK; human rights; asylum; time

\section{Introduction}

In this article, we compare the nature and human rights implications of immigration detention in Britain and France with a focus on its duration by examining case law, political debates and academic literature on these sites. There are a number of important similarities between these neighbouring countries. Neither, for instance, offers a clear explanation of the purpose of immigration detention. Immigration Removal Centres (IRCs) in Britain have no statutorily defined goal. ${ }^{1}$ French law like-

\footnotetext{
*) This research was funded by Mary Bosworth’s ERC Starter Grant 313362, 'Subjectivity, Identity and Penal Power'. We would like to thank the guest editors for their helpful feedback as well as Serge Slama and Lucia Zedner both of whom commented on earlier drafts.

1) S. Shaw (2016) Review into the Welfare in Detention of Vulnerable Persons, London: HMSO, Cm 9186; D. Wilsher (2012) Immigration Detention: Law, History, Politics, Cambridge: Cambridge University Press; M. Bosworth (2014) Inside Immigration Detention: Foreigners in a Carceral Age, Oxford: Oxford University Press; C. Costello (2015) 'Immigration Detention: The Grounds Beneath Our Feet', Current Legal Problems, pp. 1-35. Costello argues that immigration detention is groundless.
} 
wise does not define the purpose or rationale for detaining foreigners, merely emphasising that Centres de Rétention Administrative (CRAs) are not prisons. Placing irregular migrants in detention is an administrative decision, and should not be considered coercive in character. ${ }^{2}$ CRAs are places of 'retention', the Ministry of the Interior emphasizes, not 'detention' or 'imprisonment'. ${ }^{3}$

For both governments immigration detention is a necessary part of managing migration and, increasingly, for dealing with matters of national security. It is a means of stemming the flow of irregular arrivals and removing those with no right to remain. National and European courts, entrusted with the protection of human rights, have endorsed this view. Yet, critics, on both sides of the Channel point out that matters are more complicated; detention in both places causes psychological distress, is arbitrary, inefficient, and expensive. It separates families and returns people to difficult social and economic conditions in countries where they may have no meaningful ties. $^{4}$

Notwithstanding similarities in their immigration and asylum systems and human rights law, Britain and France take distinct approaches to the duration of detention. Britain eschews a statutory upper time limit, meaning that detainees are unsure how long they will be held. France, in contrast, operates with a strict maximum period of 45 days.

This article explores the impact of these temporal tactics on the nature of immigration detention as well as on its justification and effects. Duration, we suggest, needs to be considered qualitatively, rather than quantitatively. Trying to determine the relative merits of the shorter French or lengthier British system overlooks deeper humanitarian concerns. Instead, we demonstrate how in both systems, a period of detention raises human rights issues tied to the conditions, governance and experience of confinement as well as to the access and enforcement of such rights. In short, it is not a question of getting the period of detention 'right', we argue, but of asking why or whether we must detain at all. Before turning to such matters, we briefly sketch the system in both countries.

\footnotetext{
${ }^{2)}$ N. Fischer \& M. Darley (2010) 'Le Traitement de l'Immigration, entre Logique Administrative et Logique Pénale,’ VII Champ Pénal/Penal Field.

3) Ministère de l'Intérieur (2015) Les Centres de Rétention Administrative, Paris.

4) J. Phelps (2009) Detained Lives, London: London Detainee Support Group; HMIP and ICIBI (2012) The Effectiveness and Impact of Immigration Detention Casework: a Joint Thematic Review, London: Crown Copyright/Her Majesty Inspectorate of Prisons and the Independent Chief Inspector of Borders and Immigration; All Party Parliamentary Group on Refugees \& the All Party Parliamentary Group on Migration (APPG) (2015) Report of the Inquiry into the Use of Immigration Detention in the United Kingdom, A Joint Inquiry by the All Party Parliamentary Group on Refugees \& the All Party Parliamentary Group on Migration; Shaw (2016), n. 1; CIMADE, ASSFAM, Forum Réfugiés, France Terre d'Asile \& l'Ordre de Malte (2015) Rapport 2014 Sur les Centres et Locaux de Rétention Administrative; N. Fischer (2013) 'Bodies at the Border: The medical protection of immigrants in a French Immigration Detention Centre’, 7 Ethnic \& Racial Studies, pp. 1162-1179.
} 


\section{Immigration Detention centres in Britain and France: An Overview}

The UK government has long had powers to detain and deport foreign nationals. Yet, the first purpose built institution, the Harmondsworth Immigration Detention Unit, only opened in $1970 .{ }^{5}$ Before then, suspect foreign populations were held in prison, temporary accommodation at ports, or, during the two World Wars, in internment camps. ${ }^{6}$

Today, around 3,500 women and men are held across 9 Immigration Removal Centres (IRCs) that are run, under contract to the Home Office, by private custodial companies and HM Prison Service. Annually, this figure grows tenfold. ${ }^{7}$ An additional, undisclosed number of men, women and children are held in police cells, immigration reporting centres, or in hospital while up to 1,000 bed spaces are available in prison, most of which are set aside for ex-prisoners who have finished their sentence and are awaiting deportation. Around 100 others are held for up to five days in short-term holding facilities (STHF) at ports and airports. Finally, the Home Office operates a 'Pre-departure accommodation' facility for up to nine families near Gatwick. ${ }^{8}$ Families may be held there, or in IRC Tinsley House down the road, for 72 hours at a time. ${ }^{9}$

In France, too, confinement has been part of immigration control for a long time. From internment of exiles fleeing the Spanish civil war in the mid $1930 \mathrm{~s}^{10}$ to the camps used by the Vichy regime to hold foreign Jews from Poland or Czechoslovakia in the 1940s, ${ }^{11}$ different spaces have been allocated to segregate and confine foreigners. ${ }^{12}$ With the creation of the European Union and the introduction of the Schengen space, immigration detention has evolved in scope and in kind. Until the early 1980s, the confinement of foreign nationals occurred without much public scrutiny or comment, and without a clear legal framework. The newspaper La Marseil-

\footnotetext{
5) M. Bosworth (2014), n. 1; Wilsher (2010), n. 1.

6) R. Cohen (1994) Frontiers of Identity: The British and Others, London: Longman; C. Holmes (1988) John Bull's Island: Immigration and British Society, 1871-1971, Basingstoke: Macmillan; P. Panayi (1994) Immigration, Ethnicity and Racism in Britain: 1815-1945, Manchester: Manchester University Press; R. Hansen (2000) Citizenship and Immigration in Post-War Britain: The Institutional Origins of Multicultural Nation, Oxford: Oxford University Press.

7) Home Office (2014) Immigration Statistics July-September 2014, London.

8) HMIP (2014) Guidance: Cedars pre-departure accommodation information, London.

9) In exceptional circumstances, and only with ministerial authority, the period of confinement may be extended to one week.

10) G. Dreyfus-Armand \& E. Temime (1995) Les Camps Sur la Plage. Un Exil Espagnol, Paris: Autrement.

11) A. Grynberg (1991) Les Camps de la Honte, les Internés Juifs dans les Camps Français (193944), Paris: La Découverte; R. Schor (1996) Histoire de l'Immigration en France de la fin du XIXème siècle à Nos Jours, Paris: Armand Colin.

12) The end of the war also marked the beginning of stringent immigration policies aimed at managing and controlling migration flux. These policies included measures of deportation and of grouping migrants (regroupement). For instance, a camp was built near Menton in southeastern France to hold clandestine Italians. See O. Clochard, Y. Gastaut \& R. Schor (2004) 'Les Camps d'Etrangers Depuis 1938: Continuité et Adaptations - du 'Modèle’ Français à la Construction de l’Espace Schengen', 2 Revue Européenne des Migrations Internationales, pp. 2-23, at pp. 6-7; D. Peschanski (2002) La France des Camps. L'Internement (1938-46), Paris: Gallimard.
} 
laise revealed in 1975 that the Préfecture de Police of Marseille had been confining and removing foreigners in Arenc - primarily migrants from Algeria - since the early 1960s. ${ }^{13}$ It took another decade for a national system with legal safeguards to be developed. ${ }^{14}$ Until then, the government relied on obscure 1938 police legislation that authorised the confinement of undocumented foreigners without any form of external or judicial review. ${ }^{15}$

There are now 27 CRAs in France and its overseas departments, which can hold up to 1,810 detainees. Over the course of 2014, 50,000 individuals passed through these places. ${ }^{16}$ Each centre's capacity should not exceed 140 places ${ }^{17}$ yet some, particularly those in overseas departments, are habitually overcrowded. ${ }^{18}$ Migrants can also be detained in Locaux de Rétention Administrative (LRAs). Like the short term holding facilities in Britain, these institutions may hold individuals prior to their removal or before transfer to a CRA. They may also be used to manage overcrowding in CRAs. Although detention in LRAs is limited to 48 hours, it may be extended by an appeal against the order of the Juge des Libertés et de la Détention (JLD) or against the administrative order of removal. It can also be extended when there is no CRA within the jurisdiction of the Cour d'Appel where the LRA is located.

In both countries, the majority of detainees are removed, released or deported within 28 days. In 2013, over 80\% of the immigration detainees in the UK had been held for less than two months. Approximately 6\% had been detained for over six months, and $1 \%$ for over a year. ${ }^{19}$ Put another way, by the immigration minister, 'The majority - 63\% - leave detention within 28 days, and the overwhelming majority - 93\% - leave within 4 months.' ${ }^{20}$ Figures obtained directly from the centres themselves, reveal a slightly different breakdown, with a higher proportion of detainees in the high security Heathrow IRCs Colnbrook and Harmondsworth staying for longer, for example, than in the lower security IRC Campsfield House. In France, the

13) Alex Panzani (1975) Une prison clandestine de la police française: Arenc, Paris: F. Maspero; E. Naylor (2015) 'Arenc : le premier centre de rétention était clandestin’, 1 Plein Droit, pp. 32-36.

14) Ministère de l'Intérieur (2015), n. 3; A. Battegay, S. Chabani, E. Naylor \& M-T. Tetu (2014), Rapport final - Annexe 12: 'Projet 'Lieux à mémoires multiples et enjeux d'interculturalité': le cas de deux lieux en cours de patrimonialisation - La prison Montluc (Lyon) et le centre de retention d'Arenc (Marseille), Lyon, p. 50.

15) A. Panzani (1975), n. 13; A. Battegay, S. Chabani, E. Naylor, M-T Tetu (2013), Lieux à mémoires multiples et enjeux d'interculturalité: le cas de deux lieux en cours de patrimonialisation - La prison Montluc (Lyon) et le centre de retention d'Arenc (Marseille), Lyon, available at: http://centremax-weber.fr/IMG/pdf/Lieux_a_memoires_multiples.pdf, accessed 10 December 2015.

16) This marks a 9\% increase in comparison to 2013. 4,000 detainees were held in LRAs (CIMADE et al. (2015), note 4).

17) Article R.553-3, CESEDA.

18) In mainland France, the maximum capacity has not been reached. However, the CRA in Mayotte, a French overseas territory in the Indian Ocean, is significantly overcrowded. Initially designed for 60 people, the Mayotte CRA has been holding over 140 persons for a number of years (CIMADE et al. (2015), n. 4, p. 60).

19) Migration Observatory (2015) Briefing: Immigration Detention in the UK, Oxford, p. 4.

20) J. Brokenshire (2015) Response to the Report of the Inquiry into the Use of Immigration Detention in the United Kingdom, A Joint Inquiry by the All Party Parliamentary Group on Refugees \& the All Party Parliamentary Group on Migration, available at: https://detentioninquiry.files.wordpress.com/2015/03/james-brokenshire-letter-to-sarah-teather.pdf. 
average time of detention currently stands at 12 days in mainland CRAs. ${ }^{21}$ Some departments such as Haute-Garonne (southwest France) and Moselle (north east) hold most of their population for longer periods; i.e. between 32 and 45 days, whereas those sites under the most population pressure from migrants, such as the Pas-deCalais department, and the overseas department, Mayotte, rarely revert to lengthy detention. ${ }^{22}$ Though short in comparison to the UK, the average time in detention in France is lengthening.

Detainees hale from all quarters of the globe in both countries, with citizens from former colonies particularly over-represented. In Britain, for instance, the top five nationalities usually include Indians, Pakistanis, Jamaicans and Nigerians. In France, a significant number are Tunisian. ${ }^{23}$ Both countries also hold a number of EU citizens. In France and Britain there are sizable populations from Albania. ${ }^{24}$ Nearly all detainees are adult men. Unaccompanied children cannot be removed and therefore should not be detained. They may be held as part of a family group. Since 2009, the number of children detained in Britain has significantly dropped. ${ }^{25}$ In France, despite similar legal protections, ${ }^{26}$ the five NGOs working in CRAs report an increase of the number of children particularly in Mayotte where their number in the local CRA has grown by nearly $60 \% .^{27}$

The reason for detention varies. In Britain in 2014, more than half of those in detention had 'sought asylum during their immigration processes' ${ }^{28}$ Just one year later, this number had dropped. 'Over 50\% of those detained have never entered the asylum system', the immigration minister James Brokenshire wrote. 'They are detained because, for example, they are foreign national offenders who the government is seeking to deport because of their criminality; or because they have entered the UK illegally, or have remained in the UK illegally once their leave has expired. ${ }^{29}$

Since the passage of the UK Borders Act 2007, all non-EEA citizens in Britain sentenced to one year of custody (or whose sentences over the past 5 years add up to the same) face mandatory deportation, as do 'prolific' and 'violent' EEA offenders. ${ }^{30}$ Anyone on a deportation order can be detained. Individuals can appeal their deportation, and human rights protections should prevent the expulsion of those who are stateless or facing persecution in their home country. ${ }^{31}$ Detainees can also challenge

\footnotetext{
21) CIMADE et al. (2015), n. 4, p. 16.

22) CIMADE et al. (2015), n. 4, p. 17.

23) CIMADE et al. (2015), n. 4 p. 14. Tunisian nationals are also held for the longest periods of time (see CIMADE et al. (2015), p. 13, 17).

${ }^{24)}$ M.L. Basilien, O. Doukouré \& F. Tercero (2013), National Report France - Immigration detention \& the Rule of Law, London: Bingham Centre for the Rule of Law; Shaw (2016), n. 1.

${ }^{25)}$ A. Cooke (2013) National Report: United Kingdom - Immigration detention \& the rule of law, London: Bingham Centre for the Rule of Law; Migration Observatory (2015) Briefing: Immigration Detention in the UK, Oxford.

26) Article L. 511-4, CESEDA.

27) CIMADE et al. (2015), n. 4, p. 11.

28) Home Office (2014), n. 7.

29) Brokenshire, n. 20.

30) Kaufman (2015), 'Punish and Expel - Border Control, Nationalism, and the New Purpose of the Prison', Clarendon Studies in Criminology.

${ }^{31)}$ Bosworth (2014), n. 1.
} 
their confinement under Article 3 of the European Convention on Human Rights (ECHR), according to which they should not be exposed to inhuman or degrading treatment. ${ }^{32}$ However, access to such Human Rights protections has become increasingly restricted in recent years, as we will discuss in more detail below, rendering this sizable population liable to detention in greater numbers.

In France, only foreign nationals who are waiting removal should be placed in detention. ${ }^{33}$ The vast majority are subject to a deportation order (Obligation de Quitter le Territoire Français) due to their irregular immigration status. ${ }^{34}$ Such people may have come to France without a visa or may have failed to renew their residence permit. Asylum is not a ground for detention, and the application for asylum suspends the enforcement of the removal order. Since only those facing removal are exposed to detention, asylum seekers should not, in theory, be confined. Yet, since Dublin II requires asylum seekers to be deported to the country where they originally entered the Schengen area or to the country where they have filed an asylum claim, some detainees have active asylum cases. ${ }^{35}$ Others may not have had the time to file their application for asylum while still others may have started the process for registration before being arrested while awaiting the official confirmation of their status. In certain areas like Paris, procedures tend to take longer. ${ }^{36}$ There, asylum seekers are more likely to be arrested and placed in administrative detention.

\section{Time and Removal: The Administrative Rationale for Immigration Detention}

Immigration detention in Britain and France reflects national law and practice as well as international human rights frameworks. Together national and international instruments set out the baseline for the conditions in detention and, in most EU member states other than Britain, its duration. ${ }^{37}$ Though such frameworks may feel far removed from daily life in custodial institutions, ${ }^{38}$ they embody the main protections available to detainees.

Under Article 5(1)f of the European Convention on Human Rights, foreign nationals may be detained to prevent their unlawful entry, and to deport or remove

\footnotetext{
32) Shaw (2016), n. 1, Appendix 4.

33) Article L. 554-1, CESEDA.

34) Direction de l'information légale et administrative - Paris (2014) Rapport au Parlement - Année 2013: Les étrangers en France.

35) CIMADE et al. (2015), n. 4, p. 18; Basilien et al., (2013), n. 24, pp. 4-5.

36) Basilien et al., (2013), n. 24.

37) Denmark and Ireland have also opted out of the EU Returns Directive. However, Denmark has transposed parts of the directive into its national law. In Ireland, asylum seekers can be detained under orders of a District Judge for 21 consecutive 'committals' until the application is decided but there are no upper limits for the number of committed so asylum seekers could in theory be detained indefinitely.

38) M. Bosworth (2011), 'Human Rights and Immigration Detention', in: Marie-Bénédicte Dembour \& Toby Kelly (eds.), Are Human Rights for Migrants? Critical Reflections on the Status of Irregular Migrants in Europe and the United States, Abingdon: Routledge, pp. 165-183.
} 
them from territory in which they are unlawfully present. ${ }^{39}$ Determining who is unauthorised, either at the point of entry or within the nation state, is subject to a range of international laws and agreements from the fundamental protections in the 1951 Refugee Convention and the European Convention on Human Rights, to the Schengen Treaty, the Dublin Conventions and various, national, immigration, asylum and criminal justice acts. ${ }^{40}$ In 1990 Europe adopted the Dublin Convention to try to ensure that individuals seeking asylum are processed at the first point of entry. ${ }^{41}$ Eighteen years later, the EU Returns Directive of 2008 set the maximum period for detention prior to deportation at 6 months, extendable to 18 months. ${ }^{42}$ The Directive provides that detention should only be used for the purpose of removing illegal migrants, and is subject to the principle of proportionality with regards to the means used and objectives pursued.

The UK plays an inconsistent role in EU migration policy, sometimes participating in transnational agreements, and at other times standing aloof. Thus, while a signatory to the Dublin Protocols, it has neither signed the Returns Directive nor the Schengen agreement. In its approach to immigration detention, Britain is particularly confounding. On the one hand, through its lead National Preventative Mechanism (NPM), the HM Prison Inspectorate (HMIP), it champions the creation of minimum standards of care and seeks to reform detention practices in other member states, while on the other, in its refusal to agree to an upper limit on the period a person may be detained, Britain deviates from standard practice elsewhere. ${ }^{43}$

This approach to time has, in recent years, generated considerable critique from international human rights organisations including the Commission for Human Rights of the Council of Europe in 2008, ${ }^{44}$ and the Committee on Migration, Refugees and Population of the Parliamentary Assembly of the Council of Europe. ${ }^{45}$ National organisations have taken a similar view. The London Detainee Support group, now known as Detention Action, has been particularly vocal in this regard calling many times for a maximum time limit. ${ }^{46}$ Detention should be limited to one-month

39) B. Nicholas \& R. Husain (2003) Immigration, Asylum and Human Rights, Blackstone’s Human Rights, p. 125.

40) On these see, for example R. Thomas (2011) Administrative Justice and Asylum Appeals: A Study of Tribunal Adjudication, Oxford: Hart Publishing; G. Cornelisse (2010) Immigration Detention and Human Rights: Rethinking Territorial Sovereignty, Amsterdam: Brill; A. Aliverti (2013) Crimes of Mobility, Abingdon: Routledge.

41) Amended twice since then, at the time of writing, this agreement has partially been suspended as the mass influx of people fleeing Syria and elsewhere, has made it untenable. They simply cannot all be processed at their geographical entry point to Europe.

42) EU Returns Directive 2008/115/EC, Articles 15.5-15.6.

43) APPG, n. 4.

44) T. Hammarberg (2008) Memorandum by Thomas Hammarberg Commissioner for Human Rights of the Council of Europe, Strasbourg.

45) Committee on Migration, Refugees and Population, Parliamentary Assembly of the Council of Europe (2010) Report: The Detention of Asylum Seekers and Irregular Migrants in Europe, Strasbourg.

46) See, for example Detention Action (2012) 'Submission to the UN Special Rapporteur on the Human Rights of Migrants: Immigration Detention in the UK’; Phelps (2009), n. 4; J. Phelps (2010) No Return, No Release, No Reason: Challenging Indefinite Detention, London: London Detainee Support Group. 
they say, a position also advocated by then Chief Inspector of Prisons, Nick Hardwick. $^{47}$

In 2015, such arguments obtained a national platform when a cross-party group of politicians in the All Party Parliamentary Group on Refugees \& the All Party Parliamentary Group on Migration (APPG) held a series of public hearings and published a report. 'The United Kingdom is an outlier in not having a time limit', the APPG stressed, 'both within the EU and further afield, on the length of time an individual can be detained for immigration purposes. ${ }^{48}$ Although the Home Office guidance states that, 'detention should be used sparingly and for the shortest possible time', they asserted, 'in practice this guidance is not being adhered to. As a result, detainees are held indefinitely, which creates a stressful and anxious environment. This has significant mental health costs for detainees.' Matters were compounded, the committee went on, by the fact that 'long-term detention is not correlated with an increase in the likelihood that the Government will be able to effect removal - indeed the opposite is true. 49

France, by contrast, has been an enthusiastic proponent of EU policies. As a signatory to the Returns Directive - that was transposed into national law in 2011 - it limits immigration detention to 45 days in a system that unfolds as follows: ${ }^{50}$ once the initial period of 5 days has elapsed, the préfet can request an extension for 20 days; a period which may be renewed once. After 25 days have passed, the préfet may ask the JLD to extend the detention by 20 additional days for the following specific reasons: 1) absolute urgency, 2) serious threat to public order and 3) if the detainee has not been deported because she or he has deliberately obstructed the process, or has lost or destroyed her or his travel document or identification documents. ${ }^{51}$ After 45 days, the foreigner who has not been removed must be released. In September 2015 a new bill was introduced that would streamline matters further, prioritising house arrest and reducing the initial 5 days to 48 hours. ${ }^{52}$

In both countries, the duration of detention is closely tied to removal procedures; as Costello writes, 'pure administrative convenience is the accepted official rationale for detention'. ${ }^{53}$ In the UK, for instance, the Hardial Singh ${ }^{54}$ principles - which were reaffirmed in the 2011 Lumba UK Supreme Court decision ${ }^{55}$ - state that people should only be detained for the purpose of deportation, and for a reasonable period of time in light of the circumstances of their case. In France, the Code de l'entrée et du séjour des étrangers et du droit d'asile (CESEDA) asserts quite clearly that detention

47) HMIP (2015) Report on an Unannounced Inspection of Yarl's Wood Immigration Removal Centre by HM Chief Inspector of Prisons, London.

48) APPG, n. 4, p. 24.

49) Ibid.

50) Article L. 552-7 CESEDA.

51) Article L. 552-7 CESEDA.

52) Projet de loi relatif au droit des étrangers en France, Rapport $n^{\circ} 716(2014-2015)$ de M. François-Noël BUFFET, fait au nom de la commission des lois, déposé (30 September 2015).

53) Costello, n. 1, p. 11.

54) $R v$ Governor of Durham Prison, Ex p Hardial Singh [1984] 1 WLR 704.

55) Walumba Lumba \& Kadian Mighty $v$ Secretary of State for the Home Department [2011] UKSC 12. 
should only last for the time deemed 'strictly necessary' to organise the removal of irregular immigrants. ${ }^{56}$

Yet, in practice, considerable portions of the population in both countries are neither removed nor deported. People may also be detained for other reasons, including documentation and to enforce compliance with their immigration case. Until recently in the UK - where the system has currently been suspended following a High Court Decision $^{57}$ that was upheld in July 2015 by the Court of Appeal ${ }^{58}$ - certain foreign nationals could be held while their asylum case was handled under the fast track system.

Detention 'must comply with the European Convention on Human Rights', ${ }^{59}$ as the British immigration minister recently acknowledged. Yet, the relevant ECHR cases impose few constraints on duration. For instance in 1996, the ECtHR ruled in Amuur $v$ France ${ }^{60}$ that the detention for three weeks of a group of Somali asylum seekers in the international zone of the Paris-Orly airport was unlawful only because the legislation under which they were held was both imprecise and inaccessible, rendering their detention arbitrary. In Chahal $v U K,{ }^{61}$ the Court held that the six-year detention of a Sikh separatist leader while he appealed the decision to deport him was lawful in as much as the deportation proceeding had been handled with 'due diligence'. More recently, in Saadi $v U K,{ }^{62}$ the ECtHR found that the short detention of an asylum seeker for administrative convenience under the fast track procedure complied with article 5 (1)(f). While this decision is rendered moot by the recent suspension of fast track detention, it illustrates the emphasis placed by the Court on migration procedures, rather than the nature or impact of confinement, in its interpretation of duration.

In the 2012 case Popov v France, the European Court held that the detention of migrants' children violated Article 3. Conditions at the Rouen-Oissel centre, with its adult-sized iron-frame beds were dangerous for minors as were the automatic doors to the rooms. There were also no play areas or activities for them. The Council of Europe Commissioner for Human Rights and the European Committee for the Prevention of Torture and Inhuman or Degrading Treatment or Punishment (CPT) underscored that the stress, insecurity, and hostile atmosphere in CRAs was particularly damaging for young children, and violated international child protection principles according to which the authorities must do everything in their power to avoid detaining children for lengthy periods. While two weeks' detention was not deemed to be, in itself, excessive, the Court found it could seem very long for children living in

\footnotetext{
56) Article L. 554.1 CESEDA.

57) $R$ (Detention Action $v$ First-Tier Tribunal) (Immigration and Asylum Chamber) \& Ors [2015] EWHC 1689 (Admin).

58) The Lord Chancellor v Detention Action (Secretary of State for the Home Department an interested party) [2015] EWCA Civ 840. The suspension of the fast track system entails that asylumseekers can no longer be detained during the asylum process on the grounds that their cases could be subject to a quick decision.

59) Brokenshire, n. 20.

60) Amuur v France [1996] ECHR 25.

61) Chahal v United Kingdom [1997] 23 EHRR 413.

62) Saadi v United Kingdom [2008] 47 EHRR 17.
} 
such an ill-suited environment. The exposure to these detention conditions for this period of time, however, did not violate Article 3 of the Convention with regards to the parents, suggesting that the problem for the courts related to the protected characteristics of children, rather than to detention itself. ${ }^{63}$

National courts in Britain and France have done little to challenge detention on the grounds of duration. Although the British High Court ruled in fifteen cases between 2009 and 2011 that detainees held for over one year with little prospect of removal had been held unlawfully, ${ }^{64}$ as in the ECHR case law, the lawfulness of indefinite detention rested on the reasonable enforcement of removal procedures, rather than on detention itself. For example, in Sino, ${ }^{65}$ the High Court ruled that the detention for over four years of an Algerian man suffering from psychological disorder was unlawful because there was at no point any prospect of deportation becoming possible in a reasonable period. Following similar logic, in A v SSHD (2007) the Court upheld the detention of an asylum seeker who had refused to accept voluntary repatriation on the grounds that $A$ had the power to end his detention by agreeing to return to his country of origin. ${ }^{66}$ Finally, the Court of Appeal decision in ZA (Iraq) held that the length of time a detainee had already spent in detention was a 'highly relevant' factor to be taken into account in determining detention's lawfulness. ${ }^{67}$

In France, most of the case law similarly focuses on procedural rather than humanitarian implications of time in detention. ${ }^{68}$ On 23 September 2015, for instance, the Cour de Cassation annulled an authorization to prolong a person's detention on the basis that the relevant authority had waited too long before launching the removal process. ${ }^{69}$ Because detention is the corollary to removal decisions, authorities must complete such formalities with the utmost speed.

In all these judgements, with the partial exception of the case involving the detention of children at Rouen-Oissel, the problem with and lawfulness of detention does not inhere in the institution, its impact or conditions, but in the inability of the state to remove a person quickly enough. This jurisprudential approach ignores detainees' experience of confinement, thereby however inadvertently, drawing attention away from those who are detained. The courts' appreciation of time also fails to consider other aspects closely tied to duration such as the governance structure and daily regimes to the deleterious impact on mental health ${ }^{70}$ and 'quality of life' in detention. ${ }^{71}$ As a result, the human rights implications raised by this form of confinement, remain narrowly understood. It is to these issues that we now turn.

\footnotetext{
63) Popov v France [2012] ECHR (application numbers 39472/07 and 39474/07).

64) Detention Action, n. 46, p. 7.

${ }^{65)} R$ (on the application of Sino) v SSHD [2011] EWHC 2249 (Admin).

${ }^{66)} R$ (on the application of A) $v$ SSHD [2007] EWHC 804 (Admin).

67) ZA (Iraq), [2015] EWCA Civ 168.

68) Basilien et al., (2013), n. 24, p. 28, 29.

69) Cass. Civ. $1^{\text {ère }} 23$ September 2015, pourvoi $n^{\circ} 14.25 .064$. the court held that the approach of the weekend could not justify waiting three days before beginning the process.

70) K. Robjant, R. Hassan \& C. Katona (2009) 'Mental health implications of detaining asylum seekers: Systematic review’, 4 The British Journal of Psychiatry, pp. 306-312.

${ }^{71)}$ M. Bosworth \& B. Kellezi (2013) 'Developing a Measure of the Quality of Life in Detention’, 1 Prison Service Journal, pp. 10-15.
} 


\section{Time and Human Rights: Governance, Conditions and Uncertainty}

The state manages immigration detention in Britain and France quite differently. Whereas IRCs are contracted out to private custodial companies or to HM Prison Service, in France CRAs are operated either by the police aux frontières (PAF) or by the local police or prefecture. ${ }^{72}$ In the former, the private sector and the contracting model clearly benefits from the open-ended nature of detention, as the longer someone is detained the more places of detention are needed. In France, where the state is physically present and involved in all stages of the immigration process, the state gains little from delay.

The state is not totally absent in IRCs. The custodial companies remain accountable to an onsite Home Office 'contract monitor' whose job is to check that the contract is followed. This person also line-manages onsite immigration officers who mediate between the detainees and their immigration caseworkers based elsewhere. Immigration officers meet with detainees in 'legal visits', passing documents and information between them and their caseworkers. They are the legal representatives of the state in detention, serving removal directions and communicating decisions about bail, temporary admission and asylum. They do not, however, make those decisions.

Matters in France are different, albeit similarly complex. While the majority of CRAs are controlled and managed by the border police, the Polices Aux Frontières (PAF), since 2008, some facilities have been run by local police forces. ${ }^{73}$ In Paris, for instance, the préfecture de police supervises the CRA located in the compounds of the Paris Palais de Justice as well as the CRA in Vincennes. The police nationale agents run the Cergy LRA.

In neither country do those working within the institutions receive specific training in international or asylum law. In Britain, detention custody officers (DCOs) undergo a mere six weeks of instruction with a focus on security and 'interpersonal skills'. All DCOs must pass a course in 'control and restraint', and have a clean criminal record. In France, PAF agents are often young and inexperienced. ${ }^{74}$ In charge of running the detention centres, these police officers are also responsible for deporting migrants. This dual role shapes the ways in which centres are run and the speed with which people pass through them, as well as how detainees are perceived and treated.

Conditions of detention and daily operations in both countries are underpinned by legal instruments and operating standards. In Britain the Detention Centre Rules 2001 provides the statutory framework while the 2008 Operating Standards ${ }^{75}$ lays out minimum requirements. Further documents, such as the Operations Enforcement

72) Between 2008 and 2011, the management of CRAS was progressively transferred from the French gendarmerie officers to the PAF (see, E. Assassi \& F-N. Buffet (2014) Rapport d'Information $n^{\circ} 773$ 'La Rétention Administrative: Eviter la Banalisation, Garantir la Dignité des Personnes', Paris: Sénat, p. 30).

73) Assassi \& Buffet (2014), n. 72, pp. 30-31.

74) Assassi and Buffet (2014), n. 72, p. 66.

75) UKBA (2008) Operating Standards for Immigration Removal Centres, London: Home Office. 
Manual $^{76}$ and Detention Service Orders (DSOs), complete the official framework. In France, much is laid out in the law. Article R. 553-3 of the CESEDA, for instance, offers considerable detail about such matters as 'minimum usable surface' $\left(10 \mathrm{~m}^{2}\right.$ per detainee), then maximum figure allowed in a dormitory (six), and the size of the refectory (at least $50 \mathrm{~m}^{2}$ ).

Even though immigration detention is highly regulated in France, PAF agents enjoy broad discretion in terms of how to run the facilities. For instance, the duration detainees can be placed in isolation is not limited. It is not uncommon for detainees who are held in LRAs within police stations to be placed in cells for offenders. ${ }^{77}$ So, too, whereas detainees facing deportation must be brought before the JLD within five days to decide whether or not to extend their detention, a number are removed before this period elapses. Given that the JLD is also competent to verify the conditions of their confinement, the management of detention centres, at least for the first five days, is essentially exempt from judicial and external monitoring. ${ }^{78}$

Regimes in the detention centres of both countries are limited. While the precise nature of it in IRCs is subject to corporate confidentiality, all offer more activities than CRAs. Operating Standards ${ }^{79}$ mandate art and craft classes, IT training, English as a second language, and a range of religious and leisure activities. More recently, most centres have built 'cultural kitchens' where detainees can cook and share food with their friends. All offer some amount of 'paid work', employing detainees to serve food, clean, work as trusties ('buddies'), and, in some sites, in painting and decorating. ${ }^{80}$ They all have gymnasiums. CRAs, by contrast, may not extend much beyond a single television set and an outdoor concrete yard, while LRAs may not even include outdoor space. ${ }^{81}$

Just as the UK has been criticised for the indefinite nature of immigration detention, national and international human rights bodies have condemned the bareness of the regime and the conditions of some CRAs in France. According to Asylum in Europe, for instance, the Nice CRA is 'ill-adapted to its mission' as the premises are too small. ${ }^{82}$ In Rouen-Oissel and Paris-Vincennes, likewise, the CPT found a number of problems in the amount of heating and psychological care. The General Controller has singled out inadequate health and mental care, pointing out that dozens of suicide attempts are recorded each year across the country. ${ }^{83}$ Meals are often inadequate. In

76) UKBA (2011) Operation Enforcement Manual, London: Home Office, available at: http://www.ukba.homeoffice.gov.uk/policyandlaw/guidance/enforcement/.

77) CIMADE et al. (2015), n. 4, p. 28.

78) Given the brevity of immigration confinement, migrants are only exposed to the PAF for short periods of time. Yet, outside CRAs and LRAs walls, migrants are exposed to other forms of policing, and regular acts of violence and abuse at the hands of national police forces are reported. Notably in Marseille, Paris and Lille, migrants are often exposed to repeated intimidations, incessant identity checks and destruction of property (Amnesty International, 2014). Most recently, a video footage shows policemen beating and kicking Calais migrants who had been hiding in lorries, with the hope of crossing the Channel (Chrisafis, 2015).

79) UKBA (2011), n. 76.

${ }^{80)}$ Bosworth (2014), n. 1.

81) CIMADE et al. (2015), n. 4, p. 28.

82) Asylum In Europe (2014) National Country Report: France.

83) Contrôleur Général des Lieux de Privation de Liberté (CGLP) (2014), Rapport d'Activité. 
the centre in Palaiseau (near Paris) for instance, detainees frequently complain that the meals provided are served with non-halal meat. ${ }^{84}$ The French Senate has denounced the prison-like architecture and management of the Marseille CRA in which detainees are not free to move without being escorted by police officers and where the main courtyard is enclosed and covered with a grid. ${ }^{85}$

The duration of detention affects how the sites of confinements are run as well as the conditions in which people are held. Time also shapes the experience of detention. Ample evidence exists of the negative impact of this practice on mental health. The longer people are detained the worse they feel, ${ }^{86}$ yet, even the brief periods of detention in France have negative effects. ${ }^{87}$ Ethnographic research finds detention centres are sites of considerable depression and anxiety, with staff and detainees unclear about their purpose and legitimacy. ${ }^{88}$ Detainees find it hard to bridge language and culture barriers. Unsure about how long they will be held, they are often unable to engage with the limited regime. Instead, they wait. ${ }^{89}$

In both systems, the duration of detention is intertwined with that of the expulsion process. In the UK, where such matters may be drawn out, people can feel unmoored and unsure what to do. ${ }^{90}$ In France by contrast, it is less the brevity of the detention than the haste of the expulsion that is painful. Fears that their case may be expedited, prevent some detainees from reporting violations of their most basic rights. Others resort to self-harm, either as a result of their anxiety or, according to Annie Huraux ${ }^{91}$ in the hope of stalling their removal.

These aspects of detention raise serious human rights concerns yet have proven difficult to document or to ameliorate. There is little independent information about these sites, as governments in both countries rarely permit researchers or reporters to enter. Detainees face many barriers in making their voices heard. Problematic behaviour and conditions, under these circumstances, can pass unnoticed.

Yet, immigration detention centres are not entirely beyond scrutiny. They are not quite the Camp or the state of exception. ${ }^{92}$ Just as they are subject to the ECHR and national legal instruments, both countries play frequent host to lawyers and to human

84) CIMADE, ASSFAM, Forum Réfugiés, France Terre d'Asile \& l'Ordre de Malte (2013), Rapport 2012 Sur les Centres et Locaux de Rétention Administrative.

${ }^{85)}$ Assassi \& Buffet (2014), n. 72, p. 54.

86) Detention Action, n. 46; Shaw (2016) n. 1, Appendix 5.

${ }^{87)}$ N. Fischer (2013) 'The Detention of Foreigners in France: Between Discretionary Control and the Rule of Law', 6 European Journal of Criminology, pp. 692-708.

${ }^{88)}$ Bosworth (2014), n. 1; M. Bosworth (2015), 'Immigration Detention, Ambivalence and the Colonial Other', in: A. Eriksson (ed.), Punishing the Other, Abingdon: Routledge, pp. ...; M. Bosworth \& G. Slade (2014) 'In Search of Recognition: Gender and Staff-Detainee Relations in a British Immigration Detention Centre’, 2 Punishment \& Society, pp. 169-186.

89) S. Turnbull (2015) 'Stuck in the Middle: Waiting and Uncertainty in Immigration Detention', Time \& Society, Online first.

90) Ibid. The author of the 2016 Shaw report similarly found 'It was also clear from all my discussions with detainees that their immigration status, and the fact, length and uncertain duration of their detention, was the key determinant of their own sense of welfare.'

91) A. Huraux (2010), 'Signez Ici Monsieur', in: La Cimade (ed.) Chroniques de rétention (20082010), Arles: Actes Sud.

${ }^{92)}$ G. Agamben (2005) State of Exception, London: University of Chicago Press. 
rights NGOs in their detention centres. In France, the préfet, public prosecutors and even the Juge des Libertés et de la Détention (JLD) also visit such places. ${ }^{93}$ In the UK, immigration solicitors attend to their clients subject to restricted visiting hours.

Each IRC is attached to an official visitor group, who act as befrienders to detainees, offering them social visits and limited amounts of financial assistance or legal advice. Other charities, like Music in Detention, run classes, while Hibiscus offers advocacy and counselling for some facing deportation. NGOs in France play a more active role still. Unlike the British visitor groups, who rarely penetrate beyond the visits hall, CIMADE and 5 other organisations have offices within the CRAs to provide legal advice and assistance, ${ }^{94}$ although a decree passed in June 2014 has restrained their access. ${ }^{95}$ Their accreditation is now valid for five-years and they are only admitted to certain parts of the facilities, which does not include the police offices, the registry, the video surveillance room, maintenance amenities or the kitchen. Five people can visit for a maximum of 24 hours, Monday to Friday.

CRAs and IRCs are also subject to scrutiny from national and international human rights groups. ${ }^{96}$ Sites of detention are regulated and inspected by the national Preventive Mechanism Organisation, according to the tenets of OPCAT. In the UK the lead organisation is HMIP and in France it is the General Controller (CGLPL). Both monitor detention centres along with other sites of confinement, publishing regular reports. Members of Parliament and, less commonly, the Commissioner of Human Rights of the Council of Europe and Members of the European Parliament may also visit these sites along with the CPT. Although without a prior arrangement they may not be guaranteed access. ${ }^{97}$

\section{Conclusion: Dangerous Times}

Despite Britain and France's commitment to human rights, all too often these protections function only weakly in border control matters. Sometimes the problem is duration. Thus, in France, despite the best intentions of groups like the CIMADE, detain-

93) N. Fischer \& M. Darley (2010) 'Le Traitement de l’Immigration, entre Logique Administrative et Logique Pénale,’ VII Champ Pénal/Penal Field.

94) Fischer (2013), n. 4; N. Fischer (2009) 'Une Frontière 'Négociée’. L’Assistance Juridique Associative aux Etrangers Placés en Rétention Administrative’, 87 Politix, pp. 71-92. Until 2009, the CIMADE was the only organisation authorised by the government to provide assistance to illegal migrants held in CRAs. In April 2009, the government announced that Cimade would no longer have exclusive access to detention sites (O. Lecucq (2011) La retention administrative des étrangers en France. Entre efficacité et protection, Paris: L’Harmattan.)

95) Décret du 24 juin 2014, modifiant les articles R.553-14-4 à R.553-14-8 du CESEDA.

96) LRAs and STHFs are rather less well-scrutinised. The very spaces where LRAs are located, which include prison stations, cells within prison stations, or adjacent offices, all add to lack of visibility pertaining to detention facilities. There are also a number of other places where migrants are held far from the public eye. Such is the case of airport, harbours and railway waiting zones, hospitals or even private houses. These places of temporary detention raise issues in terms of communication of the rights, they also hinder judicial control.

${ }^{97)}$ In 2014, the British government refused to allow the UN Special rapporteur on women's rights to enter Yarl's Wood, as the visit had not been prearranged. 
ees simply may not have time to avail themselves of their assistance. ${ }^{98}$ By the time migrants receive their deportation order and get a chance to speak with a lawyer or legal representative (where language barrier will often be an issue as well as the quality of the representation), ${ }^{99}$ they may have already been deported.

At other times, however, the barriers are structural. As Human Rights Commissioner Nils Muizniekes recently pointed out, the design of the French system raises questions about that country's commitment to human rights protections. The location of the Regional Court's extension in Meaux within the immediate vicinity of the Mesnil-Amelot detention centre, he argued, raised concerns about the role of the JLD under Article $5 \S 4$ of the European Convention on Human Rights, which provides that any person deprived of his or her liberty is entitled to lodge an appeal with an independent and impartial court. Hearings held in the very place where migrants are deprived of their liberty, potentially undermining the judge's capacity for impartiality. ${ }^{100}$

Similarly while detainees in Britain can appeal the lawfulness of the decision to detain, their lack of access to legal advice and representation means that many are often unaware that these options are available. ${ }^{101}$ The legal system is not straightforward to navigate, particularly from detention. While some centres, like Colnbrook and Harmondsworth run weekly or monthly 'surgeries' with NGOs like Detention Action or Bail for Immigration Detainees, IRCs further from London find it difficult to offer similar services. Even when such facilities exist, they cannot meet the volume of requests. As a result, most of those detained rely on assistance from other detainees and the detention custody officers (DCOs) employed in the 'Welfare Office' to help fill out forms.

While many human rights organisations, particularly in the UK, have seized on duration as a means to challenge detention, time, when calculated in hours, days or weeks, only tells us so much. What may seem brief by British standards may nonetheless be experienced as interminable in France. A focus on duration is an important reminder that detention is before all a matter of personal and individualized experience, which, in the particular context of immigration, is shaped by looming removals and returns. While we have considerable evidence that being detained without being sure of when release or removal might come, is a source of fear and psychological anguish, we know too, that being deported without sufficient ability to say goodbye or to mount a legal challenge is also painful.

If campaigners in Britain hope that a time limit will improve matters, France should give them pause. To build a meaningful human rights-based critique of deten-

\footnotetext{
98) Fischer \& Darley (2010), n. 93.

99) Assassi \& Buffet (2014), n. 72, p. 60.

100) Nils Muiznieks, 'Lettre du Commissaire aux droits de l'homme du Conseil de l'Europe, Nils Muižnieks, à Mme Christiane TAUBIRA, Ministère de la Justice de la France’ (17 October 2013), available. https://wcd.coe.int/ViewDoc.jsp?id=2113877\&Site=COE\&BackColorInternet=B9BDEE\&BackColor Intranet=FFCD4F\&BackColorLogged=FFC679.

${ }^{101)}$ Bail for Immigration Detainees (BID) (2010), Report: A Nice Judge on a Good Day: Immigration Bail and the Right to Liberty, London.
} 
tion we need to have the prior discussion about confining people simply on the basis of their citizenship. Thinking about the duration of detention should not be a matter of getting the period of detention 'right', but of asking, in a more wholesale way, why or whether we must detain at all. 